\title{
Sex-related liver injury due to alcohol involves activation of Kupffer cells by endotoxin
}

\author{
Ronald G Thurman PhD
}

RG Thurman. Sex-related liver injury due to alcohol involves activation of Kupffer cells by endotoxin. Can J Gastroenterol 2000;14(Suppl D):129D-135D. Females have a greater susceptibility to ethanol-induced liver injury than males. Females who drink ethanol regularly and have been overweight for 10 years or more are at greater risk for both hepatitis and cirrhosis than males, and females develop ethanol-induced liver injury more rapidly and with less ethanol than males. Female rats on an enteral ethanol protocol exhibit injury more quickly than males and have widespread fatty changes over a larger portion of the liver lobule. Moreover, levels of plasma endotoxin, intracellular adhesion molecule-1, free radical adducts, infiltrating neutrophils and nuclear factor kappa $B$ are doubled in female rat livers compared with male rat livers after enteral ethanol treatment. Additionally, estrogen treatment in vivo increases the sensitivity of hepatic macrophages or Kupffer cells to endotoxin. Evidence has been presented that Kupffer cells are pivotal in the development of ethanol-induced liver injury. Destroying Kupffer cells with gadolinium chloride or decreasing bacterial endotoxin by sterilizing the gut with antibiotics inhibits early inflammation due to ethanol. Similar results have been obtained with anti-tumour necrosis factor-alpha antibody. These data pointed to the hypothesis that ethanol-induced liver injury involves elevations in circulating endotoxin concentrations leading to activation of Kupffer cells, which causes a hypoxia-reoxygenation injury. This theory has been tested using pimonidazole, a 2-nitroimidazole marker, to quantify hypoxia in downstream, pericentral regions of the hepatic lobule. After chronic enteral ethanol treatment, pimonidazole binding doubles. Enteral ethanol also increases free radicals detected with electron spin resonance. Radical adducts, with coupling constants such as alpha-hydroxyethyl radical, have been shown to arise from ethanol. Importantly, hypoxia and radical production detected in bile are also decreased by the destruction of Kupffer cells with gadolinium chloride. These data support the hypothesis that Kupffer cells contribute to the vital sex differences in liver injury caused by ethanol.

Key Words: Endotoxin; Ethanol; Hepatic injury; Hypoxiareoxygenation; Kupffer cells; Rats; Sex

\section{Le degré d'atteinte hépatique d'origine éthylique selon le sexe dépend de l'activation des cellules de Kupffer par les endotoxines}

RÉSUMÉ : Les femmes sont plus sujettes à l'atteinte hépatique d'origine éthylique que les hommes. En effet, celles qui boivent régulièrement et qui font de l'embonpoint depuis 10 ans et plus sont exposées à un plus grand risque d'hépatite et de cirrhose que les hommes, et chez elles, l'atteinte hépatique d'origine éthylique s'installe plus rapidement et après l'ingestion de quantités moindres d'alcool. Des rates soumises à un protocole éthylique entérique manifestent une atteinte hépatique plus rapidement que les mâles et présentent des anomalies adipeuses réparties sur une portion plus importante du lobule hépatique. De plus, les taux d'endotoxines plasmatiques, de molécule 1 de l'adhésion, d'adduits des radicaux libres, de neutrophiles infiltrants et de facteur kappa B nucléaire se trouvent multipliés par deux dans les foies des rates si on les compare aux rats soumis au même traitement. En outre, le traitement œstrogénique in vivo accroît la sensibilité des macrophages du foie (ou cellules de Kupffer) aux endotoxines. Selon les preuves accumulées, les cellules de Kupffer sont essentielles au développement de l'atteinte hépatique d'origine éthylique. La destruction des cellules de Kupffer au moyen de chlorure de gadolinium ou la réduction des taux d'endotoxines bactériennes obtenue par la stérilisation du tractus intestinal au moyen d'antibiotiques inhibe l'inflammation dès les premiers stades. Des résultats similaires ont été enregistrés avec l'anticorps dirigé contre le facteur de nécrose tumorale alpha. Ces données ont mené à l'hypothèse selon laquelle l'atteinte hépatique d'origine éthylique suppose des élévations des taux circulants d'endotoxines amenant une activation des cellules de Kupffer responsables des lésions d'hypoxie-réoxygénation. Cette théorie a été testée avec le pimonidazole, un marqueur du 2-nitro-imidazole, pour quantifier l'hypoxie dans des régions en aval et péricentrales du foie. Après le traitement à l'éthanol entérique, la fixation du pimonidazole double. L'éthanol fait aussi augmenter les taux de radicaux libres décelés par spectroscopie par résonance du spin électronique. Les adduits des radicaux, avec constantes de couplage, comme le radical de l'alpha-hydroxyéthyle, sont dérivés de l'éthanol. Fait à noter, l'hypoxie et la production de radicaux décelés dans la bile sont aussi atténuées par la destruction des cellules de Kupffer obtenue avec le chlorure de gadolinium. Ces données appuient l'hypothèse selon laquelle les cellules de Kupffer contribuent aux différences d'atteinte hépatique d'origine éthylique selon le sexe.

This mini-review was prepared from a presentation made at the 1998 World Congress of Gastroenterology, Vienna, Austria, September 6 to 11, 1998 Laboratory of Hepatobiology and Toxicology, Department of Pharmacology, The University of North Carolina at Chapel Hill, North Carolina, USA Correspondence and reprints: Dr Ronald G Thurman, Department of Pharmacology, Mary Ellen Jones Building, The University of North Carolina at

Chapel Hill, Chapel Hill, North Carolina 27599-7365, USA. Telephone 919-966-4745, fax 919-966-1893, e-mail thurman@med.unc.edu Received for publication June 15, 1999. Accepted June 23, 1999 
$\mathrm{M}$ echanisms responsible for the hepatotoxicity of ethanol have not been fully characterized despite years of research. Chronic ethanol ingestion stimulates hepatic oxygen consumption and causes fatty liver, hepatomegaly, inflammation, fibrosis and cirrhosis. Recently, exciting evidence has emerged implicating hepatic macrophages or Kupffer cells in several aspects of this pathophysiology.

Because alcoholics are susceptible to infection, interest in the effect of ethanol on the reticuloendothelial system has escalated (1). After consumption of ethanol, significant alterations in host defense mechanisms occur, including alterations in reticuloendothelial function as well as modified immune, lymphocyte, granulocyte and platelet function (2). Recently, attention has turned toward the effect of ethanol on Kupffer cells (3), which are activated by gut endotoxin or lipopolysaccharide (LPS), and have been shown to be involved in ethanol-induced liver damage (4). The hepatocyte has previously been the central focus of most studies on the effects of ethanol on liver function. The ability of Kupffer cells to eliminate and detoxify various exogenous and endogenous compounds (eg, LPS) is an important physiological regulatory function. Recent studies have demonstrated that Kupffer cells produce key mediators that stimulate ethanol metabolism (5).

Studies were hampered by the lack of an appropriate model for the examination of the mechanism of ethanolinduced liver injury in laboratory animals until Tsukamoto et al (6) introduced the in vivo rat model of continuous enteral ethanol administration. In addition to the steatosis present in other models of ethanol injury, this model exhibited several characteristics that were similar, but not exactly identical, to human alcoholic liver disease, including inflammation, pericentral necrosis and ultimately fibrosis.

It has been hypothesized that the cascade of events leading to hepatotoxicity by ethanol is initiated by an increase in circulating LPS. We hypothesized that LPS initially activates Kupffer cells to produce mediators - a necessary step in producing a hepatic hypermetabolic state (eg, the 'swift increase in alcohol metabolism' [SIAM]) in parenchymal cells. Subsequently, hypoxia occurs in pericentral regions of the liver lobule, where toxic free radicals are formed on reintroduction of oxygen, resulting in cell death (Figure 1). This article reviews new data in support of the proposal that Kupffer cells play a pivotal role in hepatotoxicity after ethanol exposure, examines sex differences and focuses predominantly on new information obtained with an enteral ethanol delivery system.

\section{GUT FLORA AND ETHANOL-INDUCED LIVER DAMAGE}

Considerable recent evidence supports the theory that the gut and LPS participate in alcoholic liver injury. LPS is one of the components of the outer wall of Gram-negative bacteria that is involved in sepsis, organ failure and lethal shock. Elevated levels of blood LPS circulating to the liver can cause hepatic tissue injury. Figure 1 illustrates our hypothesis that ethanol alters gut microflora, resulting in an increase in Gram-negative bacteria, which is the origin of LPS. Alterna-

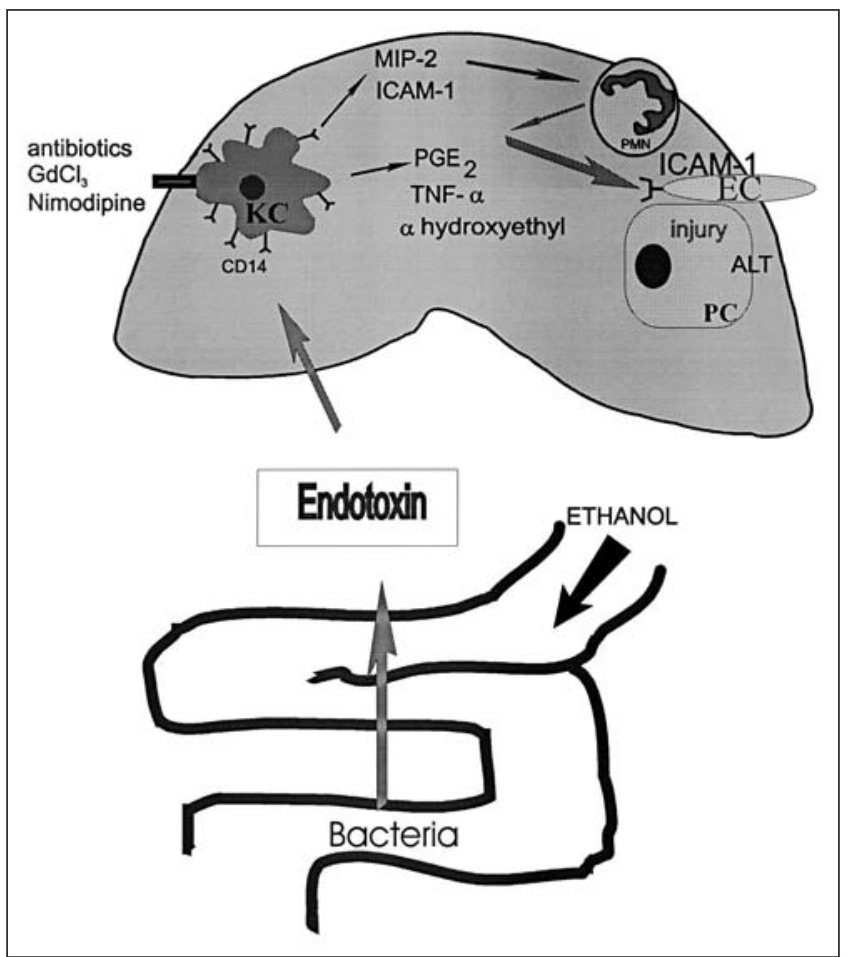

Figure 1) Working hypothesis depicting the mechanism by which ethanol elevates lipopolysaccharide (LPS) and stimulates Kupffer cells (KC). Ethanol alters gut bacteria, and an overgrowth of Gram-negative flora occurs. LPS is elevated in the blood and activates $\mathrm{KC}$ to produce receptors (CD14) and mediators such as macrophage inflammatory protein-2 (MIP-2) or intercellular adhesion molecule-1 (ICAM-1). Neutrophils (polymorphonuclear [PMN]) are activated and tumour necrosis factor-alpha (TNF- $\alpha)$ increases ICAM-1 expression on endothelial cells (EC). KC produce other chemokines such as prostaglandin $E_{2}\left(P G E_{2}\right)$ or alpha-hydroxyethyl radicals, which cause parenchymal cell (PC) injury. The inhibition of calcium channels with nimodipine, the destruction of LPS with antibiotics or the treatment with gadolinium chloride $\left(\mathrm{GdCl}_{3}\right)$, a KC toxicant, blocks the pathophysiological effects of ethanol in vivo

tively, ethanol may alter the permeability of the gut to macromolecules, thus increasing the release of LPS from the gut into the portal circulation.

\section{DIETARY EFFECTS ON ETHANOL-INDUCED INJURY}

Because undernourishment is frequently a complication of alcoholism, the effect of diet and ethanol on the gut flora is an important consideration (7). French and colleagues (7), using the enteral ethanol model, demonstrated that a diet high in unsaturated fatty acids (ie, linoleic or linolenic) is necessary for ethanol-induced liver injury. Rats fed a beef tallow diet show mild hepatic injury after chronic ethanol exposure and have normal gut bacterial flora (8). Alternatively, Gram-negative bacteria increase jejunal microflora in alcoholics (9). Furthermore, ethanol-induced liver injury using enteral ethanol feeding is decreased when gut microflora levels are diminished after treatment with lactobacillus (10) or antibiotics (11). Lactobacillus can suppress the development of a broad range of Gram-negative bacteria by produc- 
ing low molecular weight substances, whereas antibiotics obliterate bacteria. Taken together, the results of these studies are consistent with the hypothesis that gut microflora can become more virulent after exposure to ethanol.

\section{ROLE OF GUT-DERIVED LPS IN ETHANOL-INDUCED INJURY}

Under normal conditions, the gut mucosal layer allows small amounts of antigens and other macromolecules to cross into the blood. Acute and chronic treatment with ethanol increases gut permeability to hemoglobin, horseradish peroxidase and polyvinylpyrrolidone macromolecules (12). Additionally, acute exposure to ethanol in vitro increases the permeability of the isolated small intestine to labelled LPS in a dose-dependent manner (13). In alcoholics, permeability of the small intestine to labelled ethylenediamine-tetra-acetic acid is doubled (14). Physical chemical studies of interactions of lipids with membranes using electron spin resonance demonstrated that ethanol increases membrane fluidity by altering the lipid and lipoprotein composition of the cell membrane. This alteration of membrane fluidity due to ethanol may result in enhanced transport and absorption of macromolecules. Changes in membrane fluidity by ethanol were observed almost 20 years before those significant experiments that used the enteral ethanol animal model, which demonstrated that dietary requirements are involved in ethanol toxicity. However, it is still not certain whether the dietary effects that prevent hepatic injury operate at the level of the gut mucosal barrier.

\section{KUPFFER CELLS IN ETHANOL-INDUCED LIVER INJURY IN VIVO}

Several findings support the hypothesis that Kupffer cells are involved in hepatic injury caused by ethanol. First, Adachi et al (15) demonstrated that, when Kupffer cells treated with enteral ethanol in rats are inactivated by gadolinium chloride in vivo, serum enzyme levels, fatty changes, inflammation and necrosis are significantly diminished. Additionally, ethanol affects Kupffer cell functions such as phagocytosis, bactericidal activity and cytokine production (Figure 1) (16). Serum tumour necrosis factor-alpha (TNF- $\alpha$ ) levels are elevated in alcoholics (17), supporting the theory that Kupffer cells are activated in patients with alcoholic liver disease. In a recent study, plasma LPS, soluble TNF- $\alpha$ receptors and TNF- $\alpha$ were measured in patients who suffered from ethanol-induced cirrhosis (18). The data from this study were the first to report the strong correlation between plasma LPS and TNF- $\alpha$ soluble receptors in alcoholic cirrhosis. TNF- $\alpha$ is produced exclusively by the monocyte-macrophage lineage, and Kupffer cells are the primary population of this lineage (3). Lastly, Kupffer cells contain calcium ion channels, and chronic ethanol treatment promotes the opening of these channels. Intracellular calcium ion concentrations are increased twofold in isolated Kupffer cells only $2 \mathrm{~h}$ (early) after ethanol treatment in vivo. Moreover, Iimuro et al (19) recently reported that nimodipine, a calcium channel blocker, decreases ethanol-induced injury in the enteral ethanol model, suggesting that calcium channels have a crucial role in Kupffer cell activation.

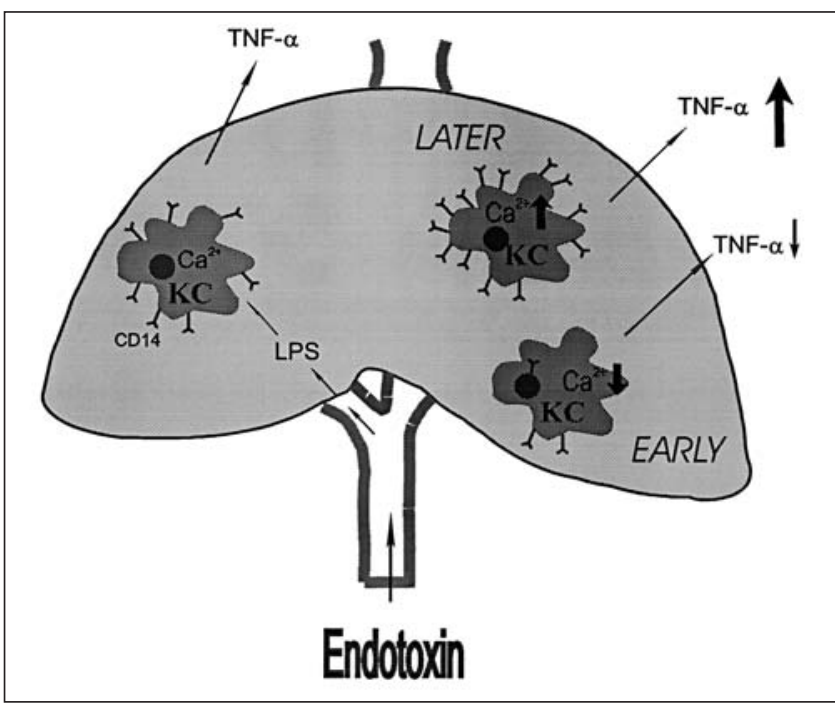

Figure 2) Hypothetical mechanism by which ethanol causes both the tolerance and sensitization of Kupffer cells (KC). As described in Figure 1, lipopolysaccharide (LPS) is elevated and removed by KC. After ethanol treatment, the tolerance of KC to LPS develops early (after approximately $2 \mathrm{~h}$ ), but sensitization develops later (after $24 \mathrm{~h}$ ). The endotoxin receptor CD-14 and the release of tumour necrosis factor-alpha (TNF- $\alpha)$ follows this pattern. CD-14 and TNF- $\alpha$ are blocked by antibiotics, thus pointing to LPS as the trigger

\section{THE ROLE OF TNF- $\alpha$ IN ALCOHOLIC LIVER INJURY}

A recent study examined temporal changes due to acute ethanol to evaluate the mechanism by which ethanol causes both the tolerance and sensitization of Kupffer cells (20). After ethanol administration, the level of blood LPS is elevated maximally at about $1 \mathrm{~h}$ (early). Initially, ethanol causes tolerance by mechanisms that are still not clear. After $24 \mathrm{~h}$ (late) of exposure to ethanol, however, CD14 and TNF- $\alpha$ are elevated sixfold and threefold, respectively (Figure 2). Additionally, sterilization of the gut with antibiotics blocks both the tolerance and the sensitization to ethanol. Taken together, these observations support the hypothesis that both of these phenomena involve LPS and Kupffer cells (20).

It is hypothesized that activated Kupffer cells release key mediators that are hepatotoxic or serve as chemoattractants for cytotoxic neutrophils that invade the liver (Figure 1). Various toxic mediators, including TNF- $\alpha$, interleukins, prostaglandins (PGs) and oxygen radicals, are released from activated Kupffer cells (21). Monden et al (22) reported that TNF- $\alpha$, superoxide and interleukin-1 inhibit protein synthesis in cultured rat hepatocytes, and that this effect can be observed in the media of cultures of activated Kupffer cells. TNF- $\alpha$ and interleukin-1, which are directly cytotoxic to a variety of cell types, may mediate hepatocyte injury. Moreover, a recent study demonstrated that rats administered ethanol enterally and injected with an antibody to TNF- $\alpha$ are protected from ethanol-induced hepatic injury (23). TNF- $\alpha$ and interleukin-1 stimulate neutrophil migration and activation, and also stimulate protease and oxygen radical release (24). Cellular infiltration of activated neutrophils, which produce 
oxygen radicals and secrete other toxic mediators, may increase the inflammatory response, leading to hepatocellular injury and death. Indeed, inflammatory cell infiltration due to enteral ethanol is diminished by gadolinium chloride treatment. Disruption of the microcirculation caused by vasoactive mediators released from Kupffer cells and neutrophils may amplify hypoxia and lead to a vicious cycle of pathophysiology.

\section{ETHANOL EXACERBATES THE EFFECT OF LPS}

Previously, it has been reported that blood LPS concentrations are often elevated in alcoholics (25). In exciting experiments using the enteral ethanol model, levels of LPS in the blood begin to rise after about two weeks of enteral ethanol treatment (26). LPS concentrations increase nearly fivefold in the systemic circulation and are possibly higher in the portal circulation. Interestingly, blood LPS correlated $(\mathrm{r}=0.84)$ with pathology (necrosis, steatosis, inflammation, etc) (26). Bode et al (25), Remmer (27) and Adachi et al (11) have consistently been proponents of the theory that LPS plays a pivotal role in ethanol-induced liver injury.

Acute exposure to ethanol also activates Kupffer cells. During acute exposure to ethanol, carbon uptake by the perfused liver due to phagocytosis of particles by Kupffer cells increases about $25 \%$ (28). Carbon uptake is also increased significantly, about $35 \%$ in rat livers treated with ethanol a few hours before liver perfusion. Similar results have been obtained in vivo (29).

Few data linking Kupffer cell function to chronic ethanol exposure exist; however, a recent study has reported that oxygen radical production by Kupffer cells is elevated after chronic ethanol ingestion (16). Others have reported that TNF- $\alpha$ release and TNF- $\alpha$ mRNA expression are increased by ethanol, which is consistent with findings that TNF- $\alpha$ levels are increased in alcoholics (29). However, a number of studies have shown that ethanol paradoxically inhibits Kupffer cell function (30). Recently, ethanol treatment has been shown to cause tolerance after $2 \mathrm{~h}$ (early), followed by sensitization in Kupffer cells after $24 \mathrm{~h}$ (late) (Figure 2). TNF- $\alpha$ production from Kupffer cells stimulated with LPS decreases about fourfold $2 \mathrm{~h}$ after ethanol treatment but is elevated about threefold $24 \mathrm{~h}$ after ethanol treatment (20). Both tolerance and sensitization are blocked by antibiotics, implicating LPS and explaining this paradox.

\section{KUPFFER CELLS PARTICIPATE IN ETHANOL-INDUCED HYPERMETABOLISM}

Israel and colleagues (31) were the first to describe a hypermetabolic state due to ethanol exposure. Moreover, Yuki and Thurman (32) showed that oxygen and ethanol uptake increased twofold 2 to $3 \mathrm{~h}$ after a single large dose of ethanol using a perfused rat liver model. They also demonstrated that the hormone-mediated depletion of liver carbohydrate reserves participates in this process, a phenomenon that has been named 'SIAM'.

Ethanol metabolism increases with a reduction in both glycolysis and glycogen reserves during SIAM (32). The involve- ment of Kupffer cells in carbohydrate metabolism has been demonstrated (33). Moreover, oxygen and ethanol uptake were almost doubled after ethanol treatment - a phenomenon blocked by gadolinium chloride (5). Thus, increases in respiration and ethanol metabolism observed after ethanol treatment are blocked by the inactivation of Kupffer cells. Specifically, Kupffer cells produce PGs, primarily $\mathrm{PGD}_{2}$ and $\mathrm{PGE}_{2}$, which enhance the production of glucose from endogenous hepatic glycogen by activating phosphorylase A (33). Additionally, conditioned media from isolated Kupffer cells of ethanol-treated rats, which contain elevated levels of $\mathrm{PGE}_{2}$, enhance parenchymal cell oxygen consumption (34). Therefore, regulation of SIAM clearly involves a Kupffer cell component, which appears to be due to production of $\mathrm{PGE}_{2}$.

\section{ETHANOL PRODUCES HYPOXIA IN PARENCHYMAL CELLS}

In addition to hypermetabolism, high doses of ethanol change hepatic microcirculation by stimulating endothelin-1 production (35). Additionally, enteral ethanol administration causes hypoxia (36). Because ethanol also causes a compensatory increase in blood flow in the liver, which may elevate hepatic oxygen levels, it has been proposed that this increase negates any effect of hypoxia due to hypermetabolism or microcirculatory disturbances (37). Therefore, pimonidazole, a 2-nitroimidazole hypoxia marker used in radiobiology to assess local hypoxia in tumours, was studied (38). Pimonidazole, which is reductively activated by nitroreductases, binds to thiol residues on macromolecule proteins in the absence of oxygen, and adducts can be detected immunochemically. Pericentral hypoxia occurs during SIAM and is blocked when Kupffer cells are destroyed with gadolinium chloride (5).

It has been reported that chronic ethanol treatment using the enteral ethanol model also causes hypoxia by using 2-nitroimidazole markers and other techniques (15). These data provide direct evidence that ethanol increases tissue hypoxia in vivo (38). By employing the hypoxia marker pimonidazole, hypoxia can be quantified in rats after a month of ethanol feeding. Image analysis techniques have demonstrated that ethanol treatment for one or four weeks causes an augmentation of pimonidazole binding in the liver from 18\% (control group) to 32\% to 35\% (ethanol-treated group) (38). Thus, direct evidence has been obtained demonstrating that hypoxia caused by ethanol treatment occurs in the clinically relevant enteral ethanol model or after acute ethanol treatment.

\section{ROLE OF FREE RADICALS IN THE MECHANISM OF ETHANOL-INDUCED LIVER INJURY}

Free radical production by ethanol has been implicated as a factor in its hepatotoxicity. Although evidence of lipid radical formation due to ethanol treatment in vivo has been reported, free radicals from ethanol alone been detected in living animals only recently (39). Ethanol-treated, alcohol dehydrogenasedeficient deermice exhibited an alpha-(4-pyridyl-1oxide)-N-t-butylnitrone (POBN)/alpha-hydroxyethyl radical adduct in bile after administration of ethanol and the spin 
trap POBN using electron paramagnetic resonance technique and spin trapping (39).

Free radical formation most likely participates in the progression of primary events in alcoholic liver disease. Rats exposed to ethanol using the Tsukamoto et al (6) model of continuous enteral ethanol administration had a free radical in bile (15). This free radical signal decreased by over $50 \%$ when Kupffer cells were destroyed after treatment with gadolinium chloride. Furthermore, bile from rats fed a control corn oil diet contains low concentrations of radical adducts. The free radical has been identified as alpha-hydroxyethyl on the basis of the 12-line spectrum obtained when ${ }^{13} \mathrm{C}$ ethanol is used (40). Thus, ethanol-derived free radicals are detected in the bile of enteral ethanol-fed rats after a high fat, ethanol-containing diet. The precise pathways responsible for the formation of free radicals remain unclear. A possible candidate is oxygen radical production by the reduced nicotinamide adenine dinucleotide phosphate oxidase system in Kupffer cells, because the electron paramagnetic resonance signal is reduced by gadolinium choride treatment. However, a reperfusion injury involving hypoxia and free radical formation via the xanthine-xanthine oxidase system and the cytochrome P450 2E1 system should not be excluded, especially because radicals in bile are expected to originate from parenchymal cells.

\section{ROLE OF SEX}

Three major independent risk factors for the development of hepatitis and cirrhosis have been identified after evaluation of 1600 alcoholic patients: consuming ethanol, being overweight for at least 10 years and being female. Sensitivity to ethanol in females is summarized in Table 1. In general, these studies demonstrate that ethanol consumption potentiates inflammatory responses, ethanol metabolism, hormone levels, hypoxia, free radicals and LPS in females. In rats, a study using enteral ethanol feeding established that ethanol causes more hepatic injury in females than in males (41). In that study, parameters including serum aspartate transaminase, pathological score, neutrophil infiltration, levels of circulating LPS and intracellular adhesion molecule-1 expression were evaluated. Interestingly, all parameters assessed were increased by ethanol treatment approximately twofold in females compared with males. The most dramatic histological change is the panlobular deposition of fat in female livers after ethanol feeding, compared with the well known pericentral localization in males. Significantly more hepatic infiltration of inflammatory cells is observed after ethanol administration in the female. It has recently been demonstrated that the LPS receptor CD14 is elevated in Kupffer cells after treatment with estriol (42). Furthermore, LPS is higher after ethanol in female rats (41). Therefore, these data are consistent with the hypothesis that LPS and Kupffer cells are responsible for the increased susceptibility of females to ethanol.

Tissue hypoxia has been quantified using the hypoxia marker pimonidazole in male and female rats after enteral ethanol feeding (43). In this study, hypoxia marker binding is two to three times stronger in females than in males after a month of ethanol treatment. Furthermore, nuclear factor kappa B is
TABLE 1

Some factors for the increased susceptibility of females to ethanol-induced liver injury

\begin{tabular}{|c|c|c|}
\hline Findings & $\begin{array}{l}\text { Species } \\
\text { studied }\end{array}$ & Reference \\
\hline Higher levels of circulating LPS & Rat & 41 \\
\hline Panlobular fat distribution in the liver & Rat & 41 \\
\hline Greater liver injury with less ethanol & $\begin{array}{l}\text { Rat } \\
\text { Human }\end{array}$ & $\begin{array}{l}41 \\
44\end{array}$ \\
\hline $\begin{array}{l}\text { Elevated intercellular adhesion molecule-1 } \\
\text { expression }\end{array}$ & Rat & 41 \\
\hline More infiltrating neutrophils & Rat & 41 \\
\hline Rapid ethanol metabolism & $\begin{array}{l}\text { Rat } \\
\text { Human }\end{array}$ & $\begin{array}{c}41 \\
45,46\end{array}$ \\
\hline Increased mortality by estrogen due to LPS & Rat & 42 \\
\hline Increased estrogen levels by ethanol & Human & 47 \\
\hline Increased ethanol-induced injury by fat & Human & 48 \\
\hline Decreased gastric alcohol dehydrogenase & Human & 49 \\
\hline $\begin{array}{l}\text { Elevated CD14 and lipid-binding protein with } \\
\text { ethanol }\end{array}$ & Rat & 20 \\
\hline Greater hypoxia and more free radicals & Rat & 50 \\
\hline Greater fibrosis & Human & 48 \\
\hline $\begin{array}{l}\text { Injury due to ethanol blocked by ovariectomy, } \\
\text { which is reversed by estrogen }\end{array}$ & Rat & 51 \\
\hline $\begin{array}{l}\text { Actin polymerization in Kupffer cells occurs only } \\
\text { when ethanol and LPS are combined }\end{array}$ & Rat & 52 \\
\hline Suppressed P450-mediated metabolism by LPS & Human & 53 \\
\hline $\begin{array}{l}\text { Lower cytokine-induced neutrophil } \\
\text { chemoattractant after LPS }\end{array}$ & Rat & 54 \\
\hline Decreased phagocytotic response to ethanol & Rat & 54 \\
\hline $\begin{array}{l}\text { Higher phospholipase A2 activity in } \\
\text { lymphocytes and neutrophils }\end{array}$ & Human & 55 \\
\hline
\end{tabular}

sensitive to oxidants and is increased seven to eight times more in females than in males. Because nuclear factor kappa $B$ also increases adhesion molecule synthesis and inflammatory cytokine production, the above data may lead to the molecular mechanism of greater injury in females due to ethanol.

The use of the rat enteral feeding model will enable further mechanistic studies to provide insight into the pathophysiology of important sex differences due to alcohol. These data collectively demonstrate that females are more susceptible than males to ethanol-induced liver injury.

ACKNOWLEDGEMENTS: The authors thank the National Institute on Alcohol Abuse and Alcoholism for partial support of this work.

\section{REFERENCES}

1. Adams HG, Jordan C. Infections in the alcoholic. Med Clin North Am 1984;68:179-200.

2. Tabakoff B, Hoffman PL, Lee JM, Saito T, Willard B, Leon-Jones F. Differences in platelet enzyme activity between alcoholics and nonalcoholics. N Engl J Med 1988;318:134-9.

3. Decker T, Lohmann-Matthes ML, Karck U, Peters T, Decker K. Comparative study of cytotoxicity, tumor necrosis factor, and 
prostaglandin release after stimulation of rat Kupffer cells, murine Kupffer cells, and murine inflammatory liver macrophages. J Leukoc Biol 1989;45:139-46.

4. Nolan JP, Leibowitz A, Vladatin AL. Influence of alcohol on Kupffer cell function and possible significance in liver injury. In: Liehr H, Green M, eds. The Reticuloendothelial System and Pathogenesis of Liver Disease. Amsterdam: Elsevier, 1980:125-36.

5. Bradford BU, Misra UK, Thurman RG. Kupffer cells are required for the swift increase in alcohol metabolism. Res Commun Subst Abuse 1993;14:1-6.

6. Tsukamoto H, Reidelberger RD, French SW, Largman C. Long-term cannulation model for blood sampling and intragastric infusion in the rat. Am J Physiol 1984;247:R595-9.

7. French SW. Nutrition in the pathogenesis of alcoholic liver disease. Alcohol Alcohol 1993;28:97-109.

8. Hentges DV, Maier BR, Burton GC, Flynn MA, Tsutakawa RK. Effect of a high-beef diet on the fecal bacterial flora of humans. Cancer Res 1977;37:568-71.

9. Bode JC, Bode C, Heidelbach R, Durr HK, Martini GA. Jejunal microflora in patients with chronic alcohol abuse. Hepatogastroenterology 1984;31:30-4.

10. Nanji AA, Khettry U, Sadrzadeh SM. Lactobacillus feeding reduces endotoxemia and severity of experimental alcoholic liver (disease). Proc Soc Exp Biol Med 1994;205:243-7.

11. Adachi Y, Moore LE, Bradford BU, Gao W, Thurman RG. Antibiotics prevent liver injury in rats following long-term exposure to ethanol. Gastroenterology 1995;108:218-24.

12. Bode JCH. Alcohol and the gastrointestinal tract. In: Frick HP, Harnack GA, Martini GA, Prader A, eds. Advances in Internal Medicine and Pediatrics. Heidelberg: Springer-Verlag, 1980:1-75.

13. Arai M. [Effect of ethanol on the intestinal uptake of endotoxin] Nippon Shokakibyo Gakkai Zasshi 1986;83:863.

14. Bjarnason I, Peters TJ. The leaky gut of alcoholism: possible route of entry for toxic compounds. Lancet 1984;i:179-82.

15. Adachi Y, Bradford BU, Gao W, Bojes HK, Thurman RG. Inactivation of Kupffer cells prevents early alcohol-induced liver injury. Hepatology 1994;20:453-60.

16. Yamada S, Mochida S, Ohno A, et al. Evidence for enhanced secretory function of hepatic macrophages after long-term ethanol feeding in rats. Liver 1991;11:220-4.

17. Stahnke LL, Hill DB, Allen JI. TNF $\alpha$ and IL-6 in alcoholic liver disease. In: Wisse E, Knook DL, McCuskey RS, eds. Cells of the Hepatic Sinusoid, 3rd edn. Leiden: Kupffer Cell Foundation, 1991:472-5.

18. Hanck C, Rossol S, Böcker U, Tokus M, Singer MV. Presence of plasma endotoxin is correlated with tumour necrosis factor receptor levels and disease activity in alcoholic cirrhosis. Alcohol Alcohol 1998;33:606-8.

19. Iimuro Y, Ikejima K, Rose ML, Bradford BU, Thurman RG. Nimodipine, a dihydropyridine-type calcium channel blocker, prevents alcoholic hepatitis due to chronic intragastric ethanol exposure in the rat. Hepatology 1996;24:391-7.

20. Enomoto N, Ikejima K, Bradford BU, et al. Alcohol causes both tolerance and sensitization of rat Kupffer cells via mechanisms dependent on endotoxin. Gastroenterology 1998;115:443-51.

21. Martinez F, Abril ER, Earnest DL, Watson RR. Ethanol and cytokine secretion. Alcohol 1992;9:455-8.

22. Monden K, Arii S, Itai S, et al. Enhancement and hepatocyte-modulating effect of chemical mediators and monokines produced by hepatic macrophages in rats with induced sepsis. Res Exp Med 1991;191:177-87.

23. Iimuro Y, Gallucci RM, Luster MI, Kono H, Thurman RG. Antibodies to tumor necrosis factor- $\alpha$ attenuate hepatic necrosis and inflammation due to chronic exposure to ethanol in the rat. Hepatology 1997;26:1530-7.

24. Thiele DL. Tumor necrosis factor, the acute phase response and the pathogenesis of alcoholic liver disease. Hepatology 1989;9:497-9.

25. Bode CH, Kugler V, Bode JC. Endotoxemia in patients with alcoholic and non-alcoholic cirrhosis and in subjects with no evidence of chronic liver disease following acute alcohol excess. J Hepatol 1987;4:8-14.

26. Nanji AA, Khettry U, Sadrzadeh SM, Yamanaka T. Severity of liver injury in experimental alcoholic liver disease. Correlation with plasma endotoxin, prostaglandin $\mathrm{E}_{2}$, leukotriene $\mathrm{B}_{4}$, and thromboxane $\mathrm{B}_{2}$. Am J Pathol 1993;142:367-73.
27. Remmer H. Die Wirkungen des Alkohols. Alkoholwirkungen 1981;17:1-11.

28. D'Souza NB, Bagby GJ, Lang CH, Deaciuc IV, Spitzer JJ. Ethanol alters the metabolic response of isolated, perfused rat liver to a phagocytic stimulus. Alcohol Clin Exp Res 1993;17:147-54.

29. Earnest DL, Abril ER, Jolley CS, Martinez F. Ethanol and diet-induced alterations in Kupffer cell function. Alcohol Alcohol 1993;28:73-83.

30. Nelson S, Bagby GJ, Bainton BG, Summer WR. The effects of acute and chronic alcoholism on tumor necrosis factor and the inflammatory response. J Infect Dis 1989;160:422-9.

31. Israel Y, Videla L, Bernstein J. Liver hypermetabolic state after chronic ethanol consumption: Hormonal interrelations and pathogenic implications. Fed Proc 1975;34:2052-9.

32. Yuki T, Thurman RG. The swift increase in alcohol metabolism: Time course for the increase in hepatic oxygen uptake and the involvement of glycolysis. Biochem J 1980;186:119-26.

33. Casteleijn E, Kuiper J, Van Rooij HC, Kamps JA, Koster JF, Van Berkel TJ. Hormonal control of glycogenolysis in parenchymal liver cells by Kupffer and endothelial liver cells. J Biol Chem 1988;263:2699-703.

34. Qu W, Zhong Z, Goto M, Thurman RG. Kupffer cell prostaglandin $\mathrm{E}_{2}$ stimulates parenchymal cell $\mathrm{O}_{2}$ consumption: alcohol and cell-cell communication. Am J Physiol 1996;270:G574-80.

35. Hijioka T, Sato N, Matsumura T, et al. Ethanol-induced disturbance of hepatic microcirculation and hepatic hypoxia. Biochem Pharmacol 1991;11:1551-7.

36. French SW, Benson NC, Sun PS. Centrilobular liver necrosis induced by hypoxia in chronic ethanol-fed rats. Hepatology $1984 ; 4: 912-7$.

37. Shaw S, Heller EA, Friedman HS, Lieber CS. Increased hepatic oxygenation following ethanol administration in the baboon. Proc Soc Exp Biol Med 1977;156:509-13.

38. Arteel GE, Iimuro Y, Yin M, Raleigh JA, Thurman RG. Chronic enteral ethanol treatment causes hypoxia in rat liver tissue in vivo. Hepatology 1997;25:920-6.

39. Knecht KT, Bradford BU, Mason RP, Thurman RG. In vivo formation of a free radical metabolite of ethanol. Mol Pharmacol 1990;38:26-30.

40. Knecht KT, Adachi Y, Bradford BU, et al. Free radical adducts in the bile of rats treated chronically with intragastric alcohol: Inhibition by destruction of Kupffer cells. Mol Pharmacol 1995;47:1028-34.

41. Iimuro Y, Frankenberg MV, Arteel GE, Bradford BU, Wall CA, Thurman RG. Female rats exhibit greater susceptibility to early alcohol-induced injury than males. Am J Physiol 1997;272:G1186-94.

42. Ikejima K, Enomoto N, Iimuro Y, et al. Estrogen increases sensitivity of hepatic Kupffer cells to endotoxin. Am J Physiol 1998;274:G669-76.

43. Iimuro Y, Kono H, Connor HD, et al. Increased susceptibility to alcoholic hepatitis in female rats is associated with elevated free radical formation. Hepatology 1996;24:1249. (Abst)

44. Blume SB. Alcohol and other drug problems in women. In: Lowinson JH, Ruiz P, Millman RB, Langrod JG, eds. Substance Abuse: A Comprehensive Textbook, 2nd edn. Baltimore: Williams \& Wilkins, 1992:794-807.

45. Holtzman JL, Gebhard RL, Eckfeldt JH, Mottonen LR, Finley DK, Eshelman FN. The effects of several weeks of ethanol consumption on ethanol kinetics in normal men and women. Clin Pharmacol Ther 1985;38:157-63.

46. Thomasson HR. Gender differences in alcohol metabolism: Physiological responses to ethanol. In: Galanter M, ed. Recent Developments in Alcoholism: Alcoholism and Women. New York: Plenum Press, 1995:163-79.

47. Gavaler JS. Alcohol effects on hormone levels in normal postmenopausal women and in postmenopausal women with alcohol-induced cirrhosis. In: Galanter M, ed. Recent Developments in Alcoholism: Women and Alcoholism. New York: Plenum Press, 1995:199-208.

48. Naveau S, Giraud V, Borotto E, Aubert A, Capron F, Chaput JC. Excess weight risk factor for alcoholic liver disease. Hepatology 1997;25:108-11.

49. Frezza M, di Padova C, Pozzato G, Terpin M, Baraona E, Lieber CS. High blood alcohol levels in women. The role of decreased gastric alcohol dehydrogenase activity and first-pass metabolism. N Engl J Med 1990;322:95-9. 
50. Kedderis GL, Argenbright LS, Miwa GT. Covalent interation of 5-nitroimidazoles with DNA and protein in vitro: Mechanism of reductive activation. Chem Res Toxicol 1989;2:146-9.

51. Yin M, Bradford BU, Thurman RG. Ovariectomy reduces alcohol-induced liver injury in rats. Hepatology 1997;26:274A. (Abst)

52. Zhang P, Spitzer JA. Acute ethanol administration modulates leukocyte actin polymerization in endotoxic rats. Alcohol Clin Exp Res 1997;21:779-83.
53. Shedlofsky SI, Israel BC, Tosheva R, Blouin RA. Endotoxin depresses hepatic cytochrome P450-mediated drug metabolism in women. Br J Clin Pharmacol 1997;43:627-32.

54. Spitzer JA, Zhang P. Gender differences in neutrophil function and cytokine-induced neutrophil chemoattractant generation in endotoxic rats. Inflammation 1996;20:485-98.

55. Kuslys T, Vishwanath BS, Frey FJ, Frey BM. Differences in phospholipase A2 activity between males and females and Asian Indians and Caucasians. Eur J Clin Invest 1996;26:310-5. 


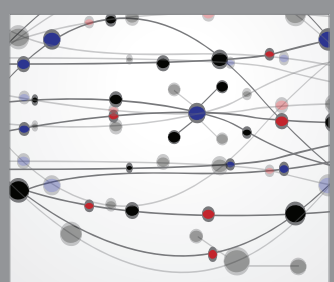

The Scientific World Journal
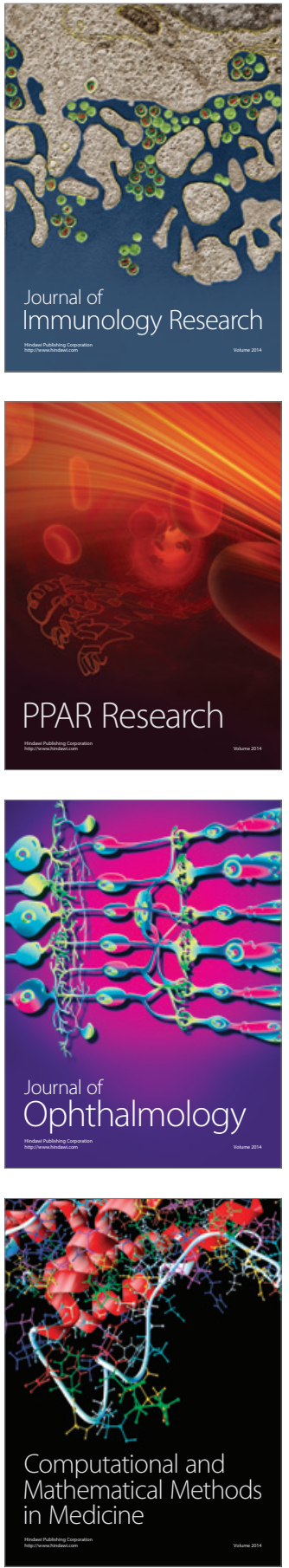

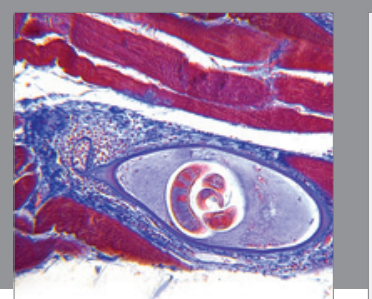

Gastroenterology Research and Practice

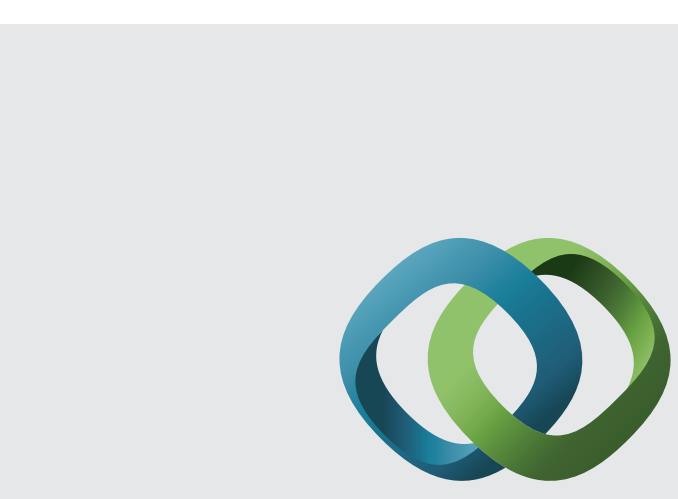

\section{Hindawi}

Submit your manuscripts at

http://www.hindawi.com
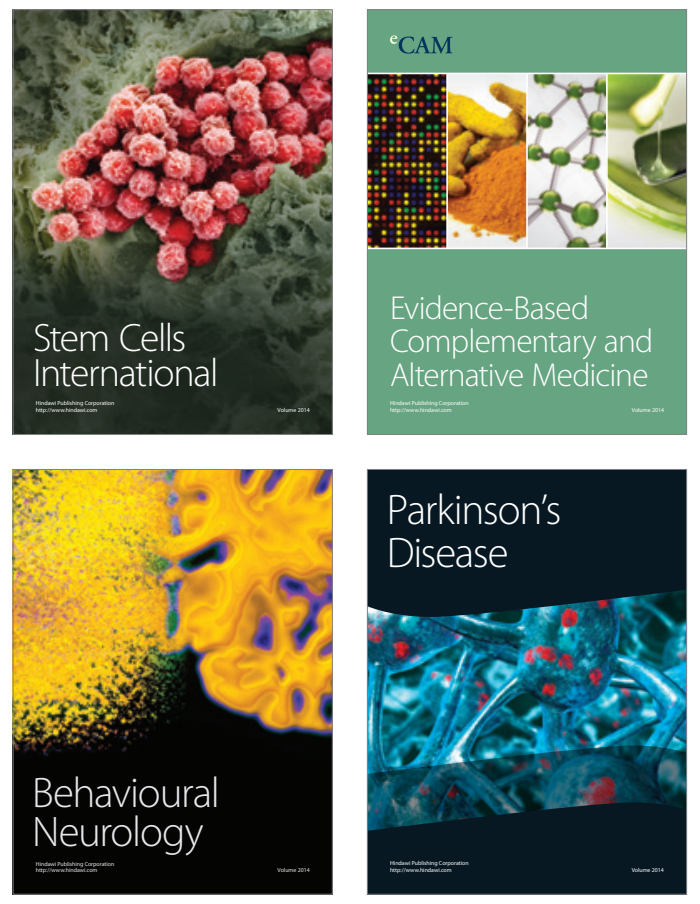
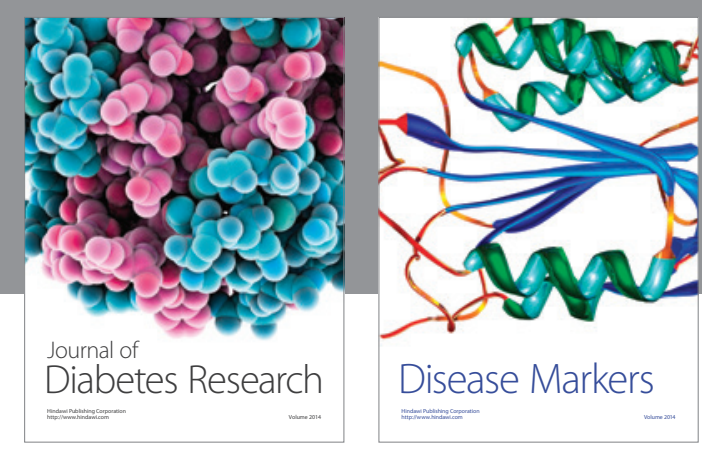

Disease Markers
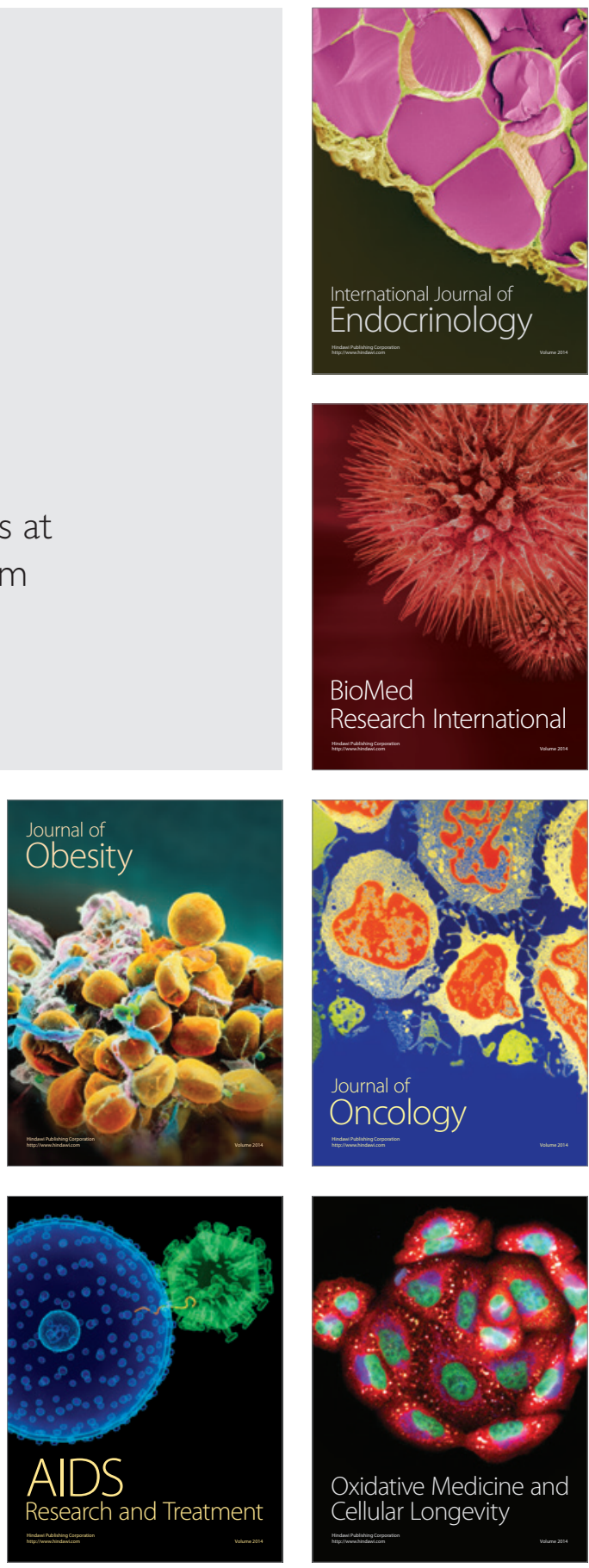